\title{
Changes in Soil Humic Acid Composition after Nine Years of Repeated Application of Organic Wastes in Black Soil: a Study Using Solid-State FT-IR and $\left({ }^{13} \mathrm{C}-\mathrm{NMR}\right)$ Analysis
}

\author{
Ahmed Sharaf ${ }^{1,2}$, Jinggui Wü, Wei Fan ${ }^{1}$, Juan Hu${ }^{1,3}$, Yaa Opoku-Kwanowaa ${ }^{1}$, \\ Mahmoud Abd El-Rahim ${ }^{1}$, Abdourazak Alio Moussa ${ }^{4}$ \\ ${ }^{1}$ College of Resource and Environmental Science, Jilin Agricultural University, Changchun, 130118, China \\ ${ }^{2}$ Soils and Water Department, Faculty of Agriculture, Al-Azhar University, Cairo, 11651, Egypt \\ ${ }^{3}$ Northeast Institute of Geography and Agroecology, Chinese Academy of Sciences, Changchun, 130102, China \\ ${ }^{4}$ College of Agronomy, Plant Biotechnology Center, Jilin Agricultural University Changchun 130118, Jilin, China
}

Received: 4 June 2020

Accepted: 27 December 2020

\begin{abstract}
In this study, soil samples under long term OW treatments were collected to analyze the changes in soil humic acid composition. The treatments in this study included a control (CK), fodder grass (FG), mushroom (MR), maize straw (MS) and tree leaves (TL) wastes. Soil HA structure was analyzed using (FTIR) and $\left({ }^{13} \mathrm{C}-\mathrm{NMR}\right)$. The results from the study showed that treatments TL, MS, FG, and MR increased soil organic carbon (SOC) by $23.45 \%, 13.83 \%, 11.90 \%$, and $5.76 \%$, respectively. Similarly, the contents of humic carbon (HAC) increased in all the OW treatments. Moreover, there was a positive relationship between O-alkyl $\mathrm{C}$ and SOC, alkyl C, soil HA contents while a negative relationship was observed between $\mathrm{O}$-alkyl $\mathrm{C}$ and aromatic $\mathrm{C}$, and carbonyl C. Compared with other treatments, $\mathrm{TL}$ and FG were also recorded as having the lowest E4/E6 ratio, $\Delta \log K$ value, and hydrophobic carbon (C)/hydrophilic carbon (C) ratio of soil HA. In conclusion, the OW treatments improved the structural characteristics of soil humic acid where the most effective treatment was TL as it higher the accumulation of SOC, soil HA, and made the structure of HA more complex and stable.
\end{abstract}

Keywords: soil HA, organic wastes $(\mathrm{OW})$, elemental analysis, $\mathrm{E}_{4} / \mathrm{E}_{6}$ ratio, black soil

*e-mail: wujingguiok@163.com 


\section{Introduction}

Black soil is the most fertile and productive soil in China. The black soil is widely distributed in Northeast China and provides a crucial source of fertile soil to support feed and food production for China and other countries. The black soil possesses high fertility and superior physicochemical properties. Over the years, SOC has decreased as a result of crop residues removal $[1,2]$. Different types of OW can change the chemical composition of SOC in the soil [3, 4]. Dou and Wang [5] showed that the interaction between soil micro-organisms and humus can lead to complete or partial decomposition of humus which results in the production of new organic matter (OM) to increase the SOC content. However, the chemical nature of the OW conceivably affects the release rates of these organic nutrients. Characteristics of soil HA depend on the humified (OM) content and fertility of the soil [6, 7]. According to the general classification of humus, it can be separated into humic acid (HAc), fulvic acid (FAc). Each type of humus structure has a special chemical composition and plays a specific role in soil fertility [810]. Many studies have been carried out on how the OW application affects soil HA composition. For example, in North China, the addition of both manure and chemical fertilizer at different rates under long term studies increased the concentration of SOC, HAc, FAc and additionally contributed to carbon (C) sequestration in soil [11]. Chen, et al. [12] reported that integrated straw residues increased carbohydrates derived O-alkyl $\mathrm{C}$ double-cropping systems form of corn residues. The application of organic manure reduced the relative contents of the aromatic $\mathrm{C}$ and alkyl $\mathrm{C} / \mathrm{O}$-alkyl $\mathrm{C}$ ratio of SOC after four years of continuous fertilization [13]. Study in semiarid areas under OW application, by [14] also suggests that increased alkyl $\mathrm{C}$, aliphatic $\mathrm{C}$ and aliphatic soil C/aromatic C HA, while found lower than o-alkyl $\mathrm{C}$ and aromatic $\mathrm{C}$ was ascribed to the decrease in methoxyl $\mathrm{C}$ and carbohydrate $\mathrm{C}$. Another study showed that the use of chemical and organic fertilizers in China black soil of increases of O-alkyl C and improves the microbial community [15]. Variable results in previous studies indicate the need for a better understanding of how the long-term application of OW affects soil HA in black soil of Northeast China. The utilization of different methods to compare the effects of OW on soil HA characterization plays an effective role in the management of agricultural systems [14, 16]. Several studies have widely utilized FT-IR and ${ }^{13} \mathrm{C}$-NMR technologies to analyze the main components of soil HA and study the chemical composition of the components $[17,18]$. In this study, we used FT-IR analysis and ${ }^{13} \mathrm{C}-\mathrm{NMR}$ to analyze soil $\mathrm{HA}$ and also discuss the effects of long term application of different OW on the composition and molecular structure of soil HA in black soil [15]. This is because few studies have been conducted on the changes in the structure and elemental composition of soil HA after long-term application of different OW in black soil. The objective of this study was to examine the effects of long-term solid OW application on the composition of soil HA in black soil by using the FT-IR and ${ }^{13} \mathrm{C}-\mathrm{NMR}$. We hypothesized that the long-term application of solid OW can increase the soil HA levels and make the soil HA structure complex.

\section{Materials and Methods}

\section{Field Experiment}

In April 2018, soil samples were collected from the Jilin Agricultural University Research Farm, Northeast China $\left(43^{\circ} 48^{\prime} \mathrm{N}, 125^{\circ} 23^{\prime} \mathrm{E}\right.$; km). Soils were classified as Udic Mollisol (according to USA soil taxonomy). The average annual temperature is $5.9^{\circ} \mathrm{C}$ while the precipitation per year is between 500 and $600 \mathrm{~mm}$. The experiment was established in 2010 and followed a randomized block design consisting of 15 plots $\left(25 \mathrm{~m}^{2}\right)$ with five treatments in three replicates. The treatments for the study included an annual input of chemical fertilizer and organic amendments at the surface of the soil. The treatments were: control (CK), fodder grass (FG), mushroom (MR), maize straw (MS) and tree leaves (TL) wastes. Application rates of OW were adjusted to similar amounts of (2600 Mg OM ha). The chemical fertilizers: N, P, and $\mathrm{K}$ were added annually at a rate of $165,82.5$, and $82.5(\mathrm{~kg})$ respectively. Soil samples were taken from the surface layer of the soil $(0-20 \mathrm{~cm})$ in each of the amended plots. The initial soil characteristics were as follows: OM $19.96 \mathrm{~g} \mathrm{~kg}^{-1}$, TN $1.26 \mathrm{~g} \mathrm{~kg}^{-1}$, TP $19.26 \mathrm{mg} \mathrm{kg}^{-1}, \mathrm{TK}, 127.02 \mathrm{mg} \mathrm{kg}$,, $\mathrm{pH}$ $\left(\mathrm{H}_{2} \mathrm{O}\right)$ 6.85. Both chemical fertilizers and OW were applied once every year before the sowing of soybean in spring. Table 1 contains information about the OW used in the present study.

\section{Chemical and Humic Composition Analysis}

The content of (SOC) was determined by the oxidation method $\mathrm{H}_{2} \mathrm{SO}_{4}-\mathrm{K}_{2} \mathrm{Cr}_{2} \mathrm{O}_{7}$ followed by the $\mathrm{FeSO}_{4}$ titration [19]. TN was determined by the Kjeldahl method while the $\mathrm{pH}$ was measured by using a $\mathrm{pH}$ meter. The available phosphorus $(\mathrm{P})$ was analyzed using sodium bicarbonate-molybdenum antimony colorimetry [20] and available potassium (K) was analyzed using a flame photometer [21]. The composition of the soil humic was analyzed using [22]. Successive extraction of soil samples with distilled water and $0.1 \mathrm{M} \mathrm{NaOH}$ $+0.1 \mathrm{M} \mathrm{Na}_{4} \mathrm{P}_{2} \mathrm{O}_{7}$ solution was obtained for humic fractions. After isolating the alkaline supernatant up to $\mathrm{pH}$ 1.0, the (HAc) was isolated from (FAc) fraction.

\section{Extraction of Soil HA}

Soil HA has been collected by the International Humic Substances Society (IHSS) according to the 
approved procedures $[23,24]$ with some modifications in the IHSS methods described by [25]. In this process, $100 \mathrm{~g}$ of soil was firstly suspended in distilled water and $0.01 \mathrm{molL}^{-1} \mathrm{HCl}$ followed by extraction using $\mathrm{NaOH}$ solution of $0.1 \mathrm{molL}^{-1}$ and 5 percent (w/v) $\mathrm{Na}_{2} \mathrm{SO}_{4}$, and $0.1 \mathrm{~mol} \mathrm{~L}^{-1} \mathrm{Na}_{4} \mathrm{P}_{2} \mathrm{O}_{7} \cdot 10 \mathrm{H}_{2} \mathrm{O}$ at $25^{\circ} \mathrm{C}$ for $48 \mathrm{~h}$. Using $6 \mathrm{~mol} \mathrm{~L}^{-1} \mathrm{HCl}(\mathrm{pH}=1.0)$, soil HA was separated and extracted. Finally, ash was removed, and the extracted samples were dialyzed to remove excess salts and then freeze-dried (Christ Alpha 1-4). An Elemental Analyzer was used to conduct the elemental (C-H-N contents) analysis of the soil $\mathrm{HA}$, while $\mathrm{O}+\mathrm{S}$ contents were determined by subtraction procedure. The soil HA solution E4/E6 ratio was measured as a measure of solution absorbances, $2.0 \mathrm{mg}$ of HA was dissolved in $10 \mathrm{~mL} 0.05 \mathrm{M} \mathrm{NaHCO}_{3}(\mathrm{pH}=8.3)$ was dissolved and $0.05 \mathrm{M} \mathrm{NaOH}$. The absorbance ratio for $\mathrm{E} 4$ and E6 was therefore at 465 and $665 \mathrm{~nm}$ respectively [26]. The $\Delta \log K$ value of soil HA (the logarithm of the absorbance at 400 and $600 \mathrm{~nm}$ ) was calculated as $\log K_{400} \mathrm{~nm}-\log K_{600} \mathrm{~nm}$.

\section{FTIR Analyses}

Soil HA sample for each treatment was analyzed using FTIR and the $\mathrm{KBr}$ technique. All samples were prepared as follows: $2 \mathrm{mg}$ of HA was mixed with $200 \mathrm{mg}$ of $\mathrm{KBr}$, finely ground in an agate mortar, and then pressed into a pellet for FTIR spectral analysis. Spectra were acquired in the 4000-400 $\mathrm{cm}^{-1}$ range with a $2 \mathrm{~cm}^{-1}$ resolution, and 32 scans were performed on each acquisition. The spectral data were processed with origin software version 8.0 including baseline corrections and atmospheric correction for $\mathrm{H}_{2} \mathrm{O}$ and $\mathrm{CO}_{2}$.

\section{${ }^{13} \mathrm{C}$ - NMR of Soil HA}

Soil HA solid-state $\left({ }^{13} \mathrm{C}\right.$ - NMR) was obtained on a Lexington spectrometer (FT-80A version) at $100 \mathrm{MHz}$. The rate was $8 \mathrm{kHz} / 50 \mathrm{~Hz}$, the contact time was 20 $\mathrm{ms}$, the spinning rate was $8 \mathrm{kHz}$, and the relaxation delay time was 20 seconds with a pulse of $90^{\circ}$. Semiquantification was performed by integration using MestReNova 5.3.1 software (Mestrelab Research S.L., Santiago de Compostela, Spain).

\section{Statistical Analyses}

Statistical package program (SPSS 17.0) and Excel 2010 were used to perform statistical analysis of the data. One-way analysis of variance (one-way ANOVA) with Duncan multiple range tests were used to determine the significant differences between treatments. Relationship analyses were conducted to test the relationships between the treatments. The obtained data were presented as mean value and \pm standard deviation (SD). The significance level was calculated at $p$-value $<0.05$

\section{Results}

\section{Effects of Solid Organic Waste on SOC and Humic Acid Carbon Content}

Long-term application of different OW increased carbon concentration in the soil (Table 2). Different amounts of carbon and $\mathrm{N}$ were applied for the different treatments as shown in (Table 1). The concentration of carbon in the various treatments varied and followed a descending order of $\mathrm{MS}>\mathrm{TL}>\mathrm{FG}>\mathrm{MR}>\mathrm{CK}$ respectively. Comparing the application rate of $\mathrm{N}$ in the experiment, slightly more $\mathrm{N}$ was applied in treatment TL compared with other OW treatments (Table 1). However, the different OW treatments (TL, MR, FG, and MS) had similar application rates of carbon (Table 1). As shown in Table 2, the concentrations of SOC were higher in all the OW treatments comparing with the control. Treatments TL, MS, FG, and MR increased SOC in soil by $23.45 \%, 13.83 \%, 11.90 \%$, and $5.76 \%$, respectively. Similarly, the contents of HAC increased in all the OW treatments. The level of HAC followed the trend of $\mathrm{TL}>\mathrm{MS}>\mathrm{FG}>\mathrm{MR}$ respectively. Additionally, HEC and $\mathrm{HAC} / \mathrm{FAC}$ increased in treatment TL comparing with the control as shown in (Table 2). In contrast, FAC did not have a similar pattern as HEC, carbon concentration and HAC. The trend for FAC was TL $>$ MS $>$ MR $>$ FG and the highest content of FAC was recorded in treatment TL, which was $27.33 \%$ higher than the control. Furthermore, the ratios of HAC/FAC were $48.97 \%$ and $32.69 \%$ higher for TL and MR respectively comparing with the other treatments. Moreover, the results of

Table 1. Basic information about the OW used in the present study

\begin{tabular}{|c|c|c|c|c|}
\hline Treatments & FG & MR & MS & TL \\
\hline $\mathrm{pH}_{(\mathrm{H} 2 \mathrm{O})}$ & 6.69 & 6.34 & 6.15 & 6.89 \\
\hline Organic C kg$^{-1}$ & 347 & 429 & 336 & 398 \\
\hline $\mathrm{Ng} \mathrm{kg}^{1}$ & 15.75 & 8.62 & 9.65 & 16.65 \\
\hline $\mathrm{P} \mathrm{g} \mathrm{kg}^{1}$ & 1.34 & 1.25 & 1.06 & 1.02 \\
\hline $\mathrm{Kg} \mathrm{kg}^{1}$ & 12.59 & 5.99 & 12.24 & 4.05 \\
\hline
\end{tabular}

FG, fodder grass treatment; MR, mushroom treatment; MS, maize straw treatment; TL, tree leaves treatment 
Table 2. SOC and soil humic composition under the different OW treatments.

\begin{tabular}{|c|c|c|c|c|c|}
\hline Treatments & SOC $\left(\mathrm{g} \mathrm{kg}^{1}\right)$ & HAC $\left(\mathrm{g} \mathrm{kg}^{1}\right)$ & FAC $\left(\mathrm{g} \mathrm{kg}^{1}\right)$ & HEC $\left(\mathrm{g} \mathrm{kg}^{1}\right)$ & HAC/FAC \\
\hline CK & $16.48 \pm 1.86 \mathrm{~d}$ & $3.21 \pm 0.03 \mathrm{c}$ & $2.27 \pm 0.38 \mathrm{bcd}$ & $5.48 \pm 0.41 \mathrm{~d}$ & $1.43 \pm 0.23 \mathrm{ab}$ \\
\hline FG & $18.44 \pm 0.95 \mathrm{~b}$ & $4.52 \pm 0.11 \mathrm{~b}$ & $2.66 \pm 0.03 \mathrm{ab}$ & $7.14 \pm 0.27 \mathrm{bc}$ & $1.68 \pm 0.90 \mathrm{ab}$ \\
\hline MR & $17.43 \pm 0.26 \mathrm{bc}$ & $4.48 \pm 0.31 \mathrm{~b}$ & $2.14 \pm 0.5 \mathrm{bcd}$ & $6.66 \pm 0.14 \mathrm{c}$ & $2.13 \pm 0.30 \mathrm{a}$ \\
\hline MS & $18.76 \pm 0.50 \mathrm{ab}$ & $4.64 \pm 0.13 \mathrm{~b}$ & $2.79 \pm 0.07 \mathrm{a}$ & $7.34 \pm 0.34 \mathrm{~d}$ & $1.62 \pm 0.09 \mathrm{ab}$ \\
\hline TL & $20.34 \pm 0.37 \mathrm{a}$ & $5.36 \pm 0.00 \mathrm{a}$ & $2.79 \pm 0.09 \mathrm{a}$ & $8.09 \pm 0.09 \mathrm{a}$ & $1.90 \pm 0.06 \mathrm{ab}$ \\
\hline
\end{tabular}

Mean values in the same column followed by the same superscript for the different treatments are not significantly different at

$P<0.05$. Values presented are the mean and \pm standard deviation of the means.

Table 3. Results of Principal component PCA analysis of SOC, $\mathrm{HAC}, \mathrm{FAC}, \mathrm{HEC}$ and $\mathrm{HAC} / \mathrm{FAC}$ under different $\mathrm{OW}$ treatments

\begin{tabular}{|c|c|c|}
\hline & PC1 & PC2 \\
\hline Eigenvalue & 3.72 & 1.24 \\
\hline Percentage & 74.40 & 25.00 \\
\hline Cumulative & 74.40 & 99.40 \\
\hline \multicolumn{3}{|c|}{ Eigenvectors coefficient } \\
\hline SOC & 0.508 & -0.114 \\
\hline HAC & 0.507 & 0.186 \\
\hline FAC & 0.406 & -0.552 \\
\hline HEC & 0.518 & 0.010 \\
\hline HAC/FAC & 0.227 & 0.805 \\
\hline
\end{tabular}

Table 4. Correlations matrix (R2) of soil humus composition under different $\mathrm{OW}$ treatments

\begin{tabular}{|c|c|c|c|c|}
\hline & SOC & HAC & FAC & HEC \\
\hline HAC & $0.927^{* * *}$ & & & \\
\hline FAC & $0.835^{* *}$ & $0.640^{*}$ & & \\
\hline HEC & $0.971^{* * *}$ & $0.980^{* * *}$ & $0.779^{* *}$ & \\
\hline HAC/FAC & 0.311 & $0.615^{*}$ & -0.209 & 0.448 \\
\hline
\end{tabular}

Correlation is significant at the 0.05 level; ** Correlation is significant at the 0.01 level, $* * *$ Correlation is significant at the 0.001 level
(Table 3) showed that PC1 accounted for $74.40 \%$ of the total contribution rate variance while PC2 accounted for $25 \%$. The cumulative contribution rate of these two principal components accounts for $94.90 \%$ of the total variance contribution rate. This indicates the relevance of using these two main components to characterize the original spectrum. In addition, there were no differences among SOC, HEC, HAC, FAC fractions for the PC1, whereas FAC showed negative correlations with other components PC2 (Table 3). HEC was more significantly correlated to HA, while FA mainly correlated to SOC and $\mathrm{HAC} / \mathrm{FAC}$ meant a higher rate contribution to soil OW faster decomposition (Table 4).

Effects of Solid Organic Waste on (C, N, H, O), $\mathrm{E}_{4} / \mathrm{E}_{6}$ Ratios, and $\Delta \log K$ Values of Soil HA

The $\mathrm{C}, \mathrm{N}$, and $\mathrm{H}$ content of soil HA under different OW treatments were as follows: C content was 48.44 to $51.51 \%$, O content was $43.05-45.34 \%$, N content was $2.52-3.15 \%$, and $\mathrm{H}$ content was $3.46-3.68 \%$ (Table 5). Compared with the control, the $\mathrm{C}$ contents of soil HA were $6.33 \%, 4.74 \%, 3.24 \%$, and $2.31 \%$ higher for TL, MS, FG, and MR respectively while the $\mathrm{O}$ contents of HA were $7.58 \%, 4.76 \%, 3.66 \%$, and $2.27 \%$ lower for TL, FG, MS, and MR respectively. This indicated that the soil HA consists mainly of elements $\mathrm{C}$ and $(\mathrm{S}+\mathrm{O})$. Treatments TL, MS, FG, and MR respectively produced $4.89 \%, 4.26 \%, 4.24 \%, 1.92 \%$ higher $\mathrm{H} / \mathrm{C}$ ratios of $\mathrm{HA}$ compared to the control. The $\mathrm{C} / \mathrm{N}$ ratio of $\mathrm{HA}$ in $\mathrm{OW}$ treatments followed the order of $\mathrm{MR}>\mathrm{MS}>\mathrm{TL}>\mathrm{FG}$ (Table 5). In addition, the $\mathrm{C} / \mathrm{N}$ ratio decreased in $\mathrm{FG}$,

Table 5. Elementary composition, $\mathrm{E}_{4} / \mathrm{E}_{6}$ ratio and $\Delta \log K$ values of soil $\mathrm{HA}$ under the different treatments.

\begin{tabular}{|c|c|c|c|c|c|c|c|c|c|}
\hline Treatments & $\mathrm{C}(\%)$ & $\mathrm{H}(\%)$ & $(\mathrm{O}+\mathrm{S})(\%)$ & $\mathrm{N}(\%)$ & $\mathrm{C} / \mathrm{N}$ & $\mathrm{H} / \mathrm{C}$ & $(\mathrm{O}+\mathrm{S}) / \mathrm{C}$ & $\mathrm{E}_{4} / \mathrm{E}_{6}$ & $\Delta \log K$ \\
\hline $\mathrm{CK}$ & 48.44 & 3.50 & 45.34 & 2.52 & 19.36 & 0.07 & 0.93 & 4.20 & 0.62 \\
\hline $\mathrm{FG}$ & 50.01 & 3.46 & 43.18 & 3.15 & 15.87 & 0.06 & 0.86 & 3.90 & 0.59 \\
\hline $\mathrm{MR}$ & 49.56 & 3.65 & 44.31 & 2.28 & 21.68 & 0.07 & 0.89 & 4.25 & 0.62 \\
\hline $\mathrm{MS}$ & 50.74 & 3.51 & 43.68 & 2.69 & 18.86 & 0.06 & 0.86 & 3.84 & 0.59 \\
\hline $\mathrm{TL}$ & 51.51 & 3.54 & 41.90 & 2.85 & 18.02 & 0.06 & 0.81 & 3.07 & 0.48 \\
\hline
\end{tabular}




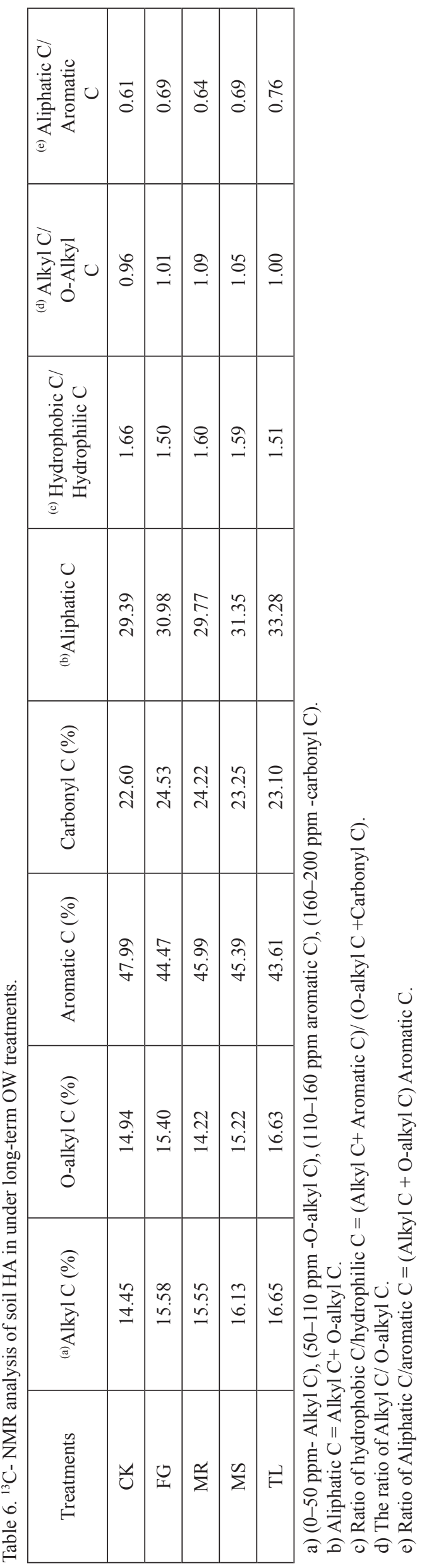

TL, MS while it increased in MR treatments compared with $\mathrm{CK}$. The $\mathrm{E}_{4} / \mathrm{E}_{6}$ ratios and $\Delta \log K$ values of $\mathrm{HA}$ samples are listed in (Table 5). The $\mathrm{E}_{4} / \mathrm{E}_{6}$ ratios and $\Delta \log K$ values of soil HA followed the order of $\mathrm{MR}>$ $\mathrm{FG}>\mathrm{MS}>\mathrm{TL}$.

\section{FTIR Analysis}

The FT-IR spectra of soil HA for each treatment and their corresponding absorbing peaks are shown in Fig. 1 and Table S1. The peak absorption positions were approximately identical among the treatments. The strongest peak was found at $2920-2850 \mathrm{~cm}^{-1}$ for the detection of aliphatic C-H and $1720-1640 \mathrm{~cm}^{-1}$ for aromatic $\mathrm{C}=\mathrm{O}$ in soil HA. The bands at about $2920-2850 \mathrm{~cm}^{-1}$ vibration of HA was more intense for treatments TL, MS, FG, and MR compared with $\mathrm{CK}$. Moreover, treatments TL and MR had a higher $\mathrm{C}-\mathrm{H} / \mathrm{C}=\mathrm{O}$ ratio whereas treatments $\mathrm{FG}$ and MS had a lower $\mathrm{C}-\mathrm{H} / \mathrm{C}=\mathrm{O}$ ratio compared with the control.

\section{$\left({ }^{13} \mathrm{C}-\mathrm{NMR}\right)$ Characteristics of Soil HA}

These spectra were characterized by the presence of many signals in the area of (0-50 ppm Alkyl C), (50-110 ppm- O-alkyl C), (110-160 ppm aromatic C), (160-200 ppm, carbonyl C). The aromatic-C and alkyl-C proportions differed significantly along the gradient height, while carboxyl-C and O-alkyl-C had similar proportions (Table 4). Compared with treatment $\mathrm{CK}$, the other OW treatments (TL, MS, FG, and MR) increased the ratio of aliphatic $\mathrm{C}$ to aromatic $\mathrm{C}$ and that of alkyl $\mathrm{C}$ to $\mathrm{O}$-alkyl $\mathrm{C}$ in soil HA. Compared with the control the aliphatic $\mathrm{C}$ of soil HA was $15.22 \%$, $11.62 \%, 7.82 \%$, and $7.61 \%$ higher for TL, FG, MS, and MR respectively (Table 6). The proportion of O-alkyl $\mathrm{C}$ in soil HA ranged from $14.9 \%$ to $16.6 \%$, aromatic $\mathrm{C}$ ranged from $47.9 \%$ to $43.1 \%$, carbonyl $\mathrm{C}$ ranged from $22.6 \%$ to $24.53 \%$ while the aliphatic $\mathrm{C}$ ranged from $29.3 \%$ to $33.2 \%$. Compared to the control, a higher aliphatic C/aromatic $\mathrm{C}$ ratio was observed for TL, FG, MS, and MR. Among all the treatments, $\mathrm{TL}$ recorded the highest aliphatic $\mathrm{C} /$ aromatic $\mathrm{C}$ ratio and alkyl $\mathrm{C} / \mathrm{O}$-alkyl $\mathrm{C}$ ratio in soil $\mathrm{HA}$. The ratio of hydrophobic $\mathrm{C}$ to hydrophilic $\mathrm{C}$ in soil HA followed the order of $\mathrm{MR}>\mathrm{MS}>\mathrm{FG}>\mathrm{TL}$ respectively. The results from Fig. 3, Table 5, and Table 6 showed that, O-alkyl C was positively correlated with SOC R2 $=(0.74, P<0.05)$, alkyl C $(\mathrm{R} 2=0.50, P<0.01)$, and soil HA contents $(\mathrm{R} 2=0.82, P<0.05)$, while it was negatively correlated with aromatic $\mathrm{C}(\mathrm{R} 2=0.51$, $\mathrm{P}<0.01)$, carbonyl $\mathrm{C}(\mathrm{R} 2=0.10, P<0.01), \mathrm{C} / \mathrm{N}$ ratio $(\mathrm{R} 2=0.76, P<0.05), \mathrm{E} 4 / \mathrm{E} 6$ ratio $(\mathrm{R} 2=0.96, P<0.01)$ and $\mathrm{H} / \mathrm{C}(\mathrm{R} 2=0.65, P<0.01)$. 


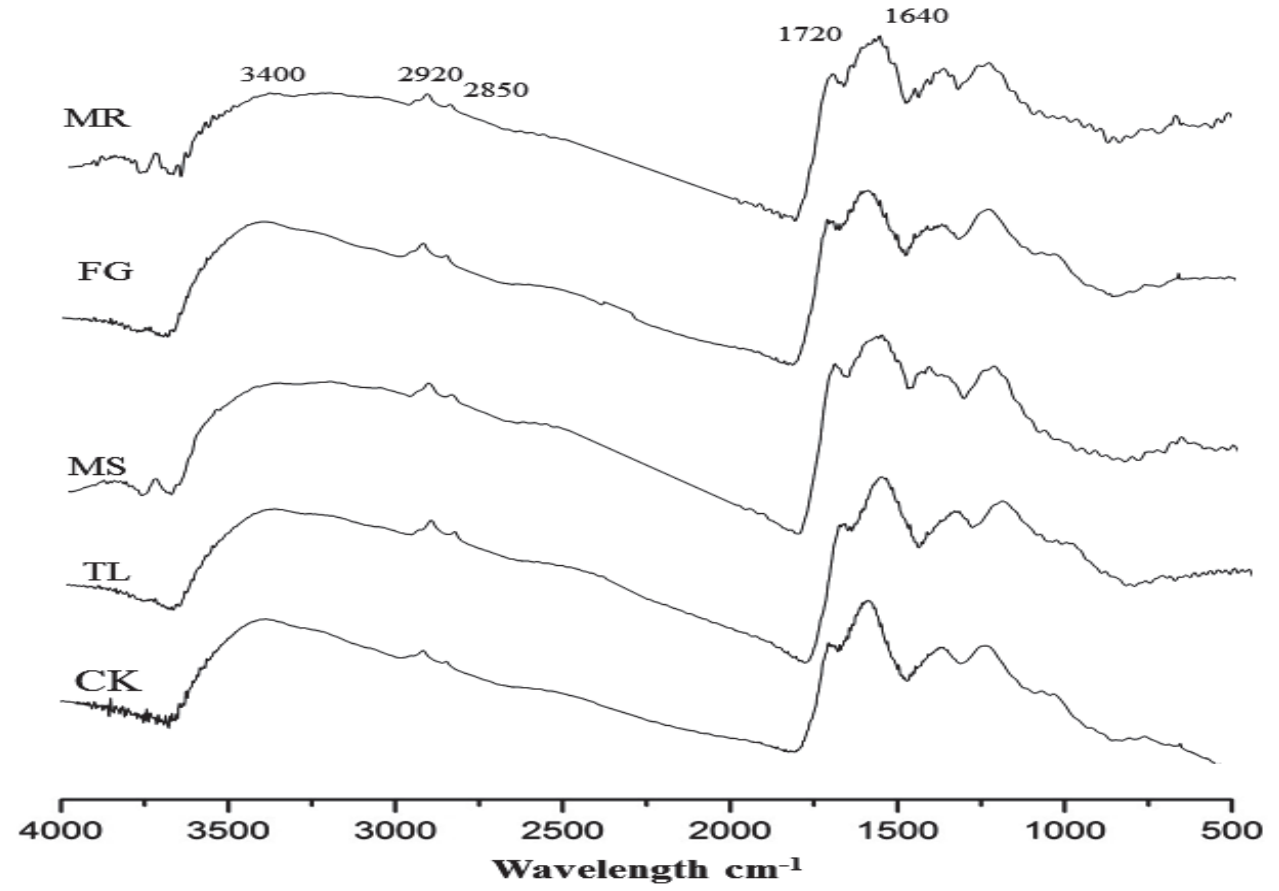

Fig. 1. FT-IR analysis of soil HA under long-term OW treatments.

\section{Discussion}

Soil HA Composition under the Different OW Treatments in Black Soil

The results of this study showed that the long term application of OW significantly increased SOC comparing with the control. The obtained data indicated that the application of $\mathrm{OW}$ is an effective tool for building and improving soil organic matter in agroecosystems [27-29]. Long term OW treatments lead to an increase in SOC, which culminates in a better balance of the requirements for plant growth and results in higher productivity [30]. In this study, among the

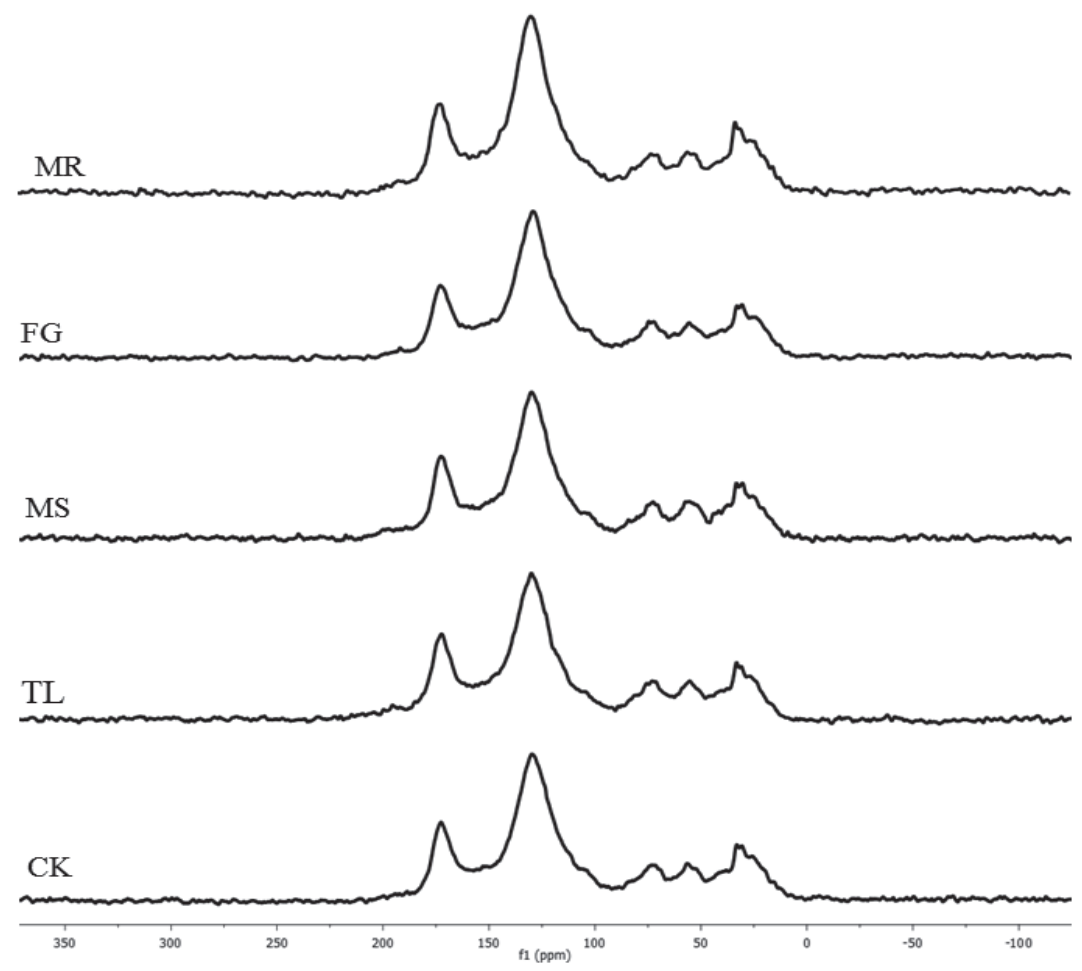

Fig. $2 .{ }^{13} \mathrm{C}$ - NMR analysis of soil HA under long-term OW treatments. 

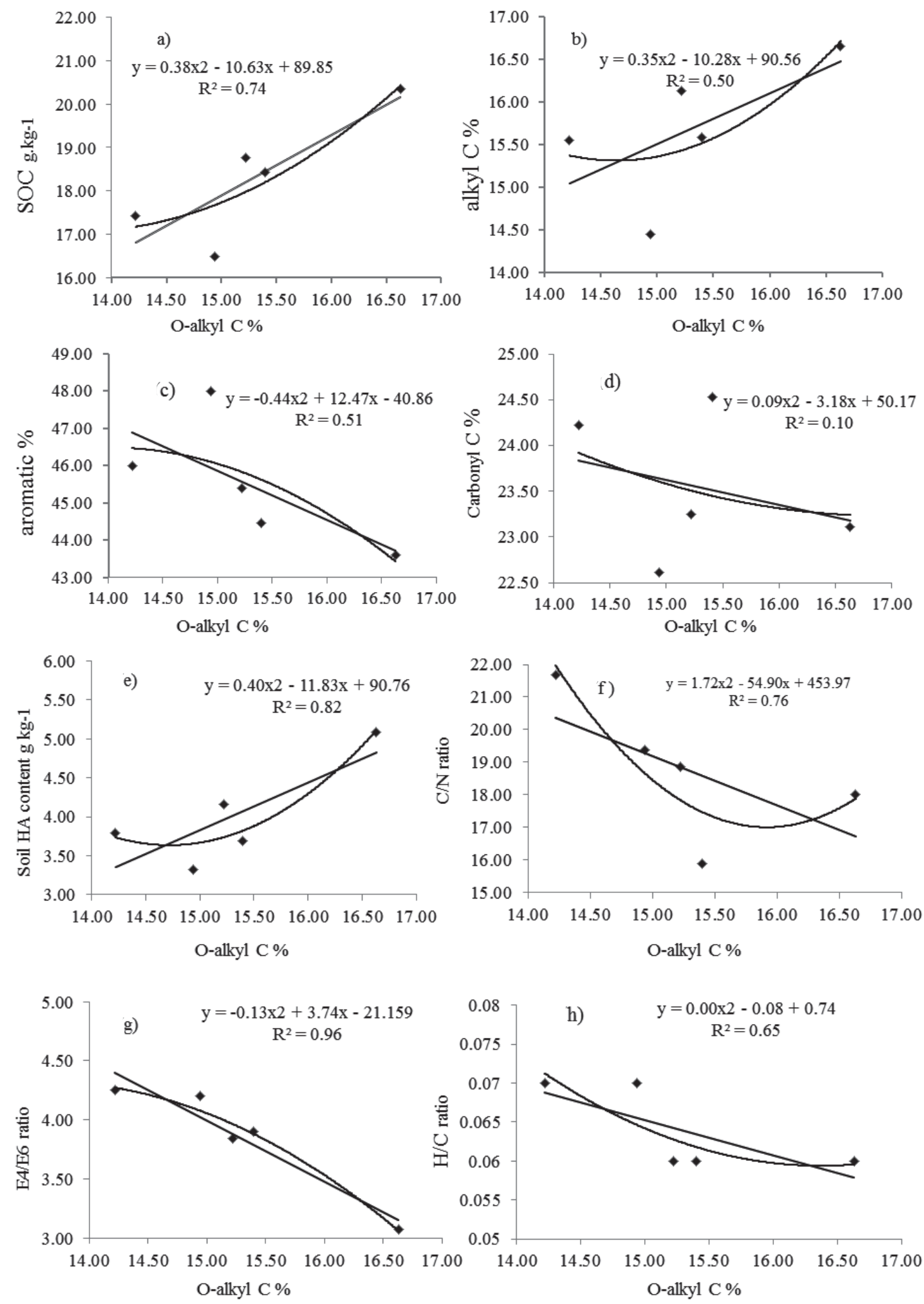

Fig. 3. Relationship between O-alkyl C and a) SOC, b) alkyl C, c) aromatic C, d) carbonyl C, e) soil HA content, f) C/N ratio, g) E4/E6 ratio, h) $\mathrm{H} / \mathrm{C}$ ratio.

OW treatments, TL recorded the highest SOC content compared with MR, FG, and MS. The other treatments also had significant increases in the concentrations of SOC; however, the increasing rate was relatively lower than TL (Table 2). This may be as a result of the high lignin content in TL. The microbial community plays an important role in the process of nutrient transformation in soil [31] and contributes to all the 
major processes of SOC cycling [32]. Yang, et al. [33] Found that organic residues decomposer faster after the NPK with organic matter amendments, because the higher biological conquest found in NPK with organic matter amendments. The composition of humic acid is heterogeneous and has a high molecular weight [34, 35]. In the present study, TL recorded the highest amount of extractable HAC, FAC, and HEC compared with the other OW treatments. The use of different OW increased SOC and HAC content as shown in (Table 2). In this study, an increase in the rate of OW addition resulted in relatively higher humus content. This observation was mainly due to the fact that carbon was preferentially converted to HAC instead of FAC in the different OW treatments [11, 36, 37]. In addition, the OW treatments had higher molecular weight and polymerization of HAC compared to FAC, as the amount of polymerization is strongly related to the humification degree [38, 39]. Moreover, the transformation of FAC into HAC enhances and increases SOC stability [40]. The findings of our study showed that the HAC/ FAC and $\mathrm{HAC} / \mathrm{HEC}$ ratios increased in the $\mathrm{OW}$ treatments, leading to an increase in the humification level. The HAC/HEC ratio was used as an indicator of humidification, where a higher ratio indicates higher weights, more complex molecular structures and higher quality of soil HA [41, 42]. The higher $\mathrm{HAC} / \mathrm{FAC}$ and $\mathrm{HAC} / \mathrm{HEC}$ ratio gave a good reflection of the degree of humification for the treatments used in this study [43]. Additionally, our findings showed that the ratios of $\mathrm{HAC} / \mathrm{FAC}$ and $\mathrm{HAC} / \mathrm{HEC}$ were higher in FG, TL, and MR treatments due to their higher degree of humification. This was in line with the study of Chen, et al. [44], Fan, et al. [45].

\section{Elemental Analysis of Soil HA and $\mathrm{E}_{4} / \mathrm{E}_{6}$ Ratios under Different OW Treatments of Black Soil}

Elemental analysis is one of the simplest and important methods for assessing humus structure and characteristics. The proportion of each element $(\mathrm{C}, \mathrm{N}, \mathrm{H}, \mathrm{O})$ in soil HA is usually used to explain the trends in its regularity to best analyze the effects of organic wastes treatments $[15,46]$. In this study, the high $\mathrm{N}$ content in $\mathrm{FG}, \mathrm{MS}$, and TL whereas low $\mathrm{N}$ content was recorded in MR. This means that the organic wastes (FG, MS, and TL) were decomposed by microorganisms thereby producing highly humified OM [47]. In general, Condensation and oxidation levels in soil HA represent the $\mathrm{H} / \mathrm{C}$ and $\mathrm{O} / \mathrm{C}$ ratios, respectively. The decrease in $\mathrm{H} / \mathrm{C}$ and $\mathrm{O} / \mathrm{C}$ ratios for $\mathrm{TL}, \mathrm{MS}$, and FG indicated high stability of soil HA, a high degree of condensation of soil HA, and highly humified OM [48, 49] and [50]. Plaza, et al. [51] reported that the $\mathrm{C} / \mathrm{N}$ ratios of soil HA increased with the application of animal manure, leading to lipids enhancement in soil $\mathrm{HA}$. These differences in $\mathrm{C} / \mathrm{N}$ ratios of soil HA may be due to the nature of the OW that was applied during the nine years $[52,53]$. The effects of OW on soil microbial communities are different due to the difference in the $\mathrm{C} / \mathrm{N}$ ratio [54]. Also, lower soil ventilation leads to low OW decomposition, leading to more carbon accumulation [55]. Low $\mathrm{H} / \mathrm{C}$ and $\mathrm{C} / \mathrm{N}$ ratio values resulted in a high level of stabilization and condensation of the soil HA and an increased humification of the OM as similar results were reported by [56]. The $\Delta \log K$ and E4/E6 are used as indexes for soil HA humification level $[57,58]$. In the following study, we found that the E4/E6 and $\Delta \log K$ values of TL, MS, and FG treated soils were lower than the control. The lower E4/E6 ratio was due to a more complex composition of soil HA [59]. This indicated that OW treatments especially TL and FG improved the aromatic condensation degrees of soil HA, and made the molecular structure complex, as clearly observed in treatment TL. This was consistent with the findings of $[14,60]$, who studied soil HA under plastic mulch conditions in northeast China. In addition to intrinsic aromas and condensation, the $\Delta \log K$ and E4/E6 are used to denote particles and molecular sizes of the soil HA [50]. In comparison with the control and the other treatments, the E4/E6 and $\Delta \log \mathrm{K}$ ratios of treatment MR were relatively higher since the soil HA became more aliphatic and complex following the application of MR.

\section{Soil HA of FTIR Analysis Different (OW) Treatments of Black Soil}

The FTIR spectrum of soil HA for the different treatments and the corresponding absorbing peaks have been shown in Fig. 2 and Table S1 respectively. In the current study, the results of the OW treatments on soil function groups of soil HA were markedly different. The $\mathrm{C}-\mathrm{H}$ and $\mathrm{C}=\mathrm{O}$ bonds were higher in the OW amended plots than control where the OW with manure contained the highest amino compounds, since soil HA residues contained the maximum hydroxyl and aliphatic compounds [61]. It was confirmed that the soil HA changes are largely due to the high HA content in the maize straw which is released to the soil following application [62]. This made the molecular structure of black soil HA become aliphatic, complex and stable. Furthermore, the analysis of FT-IR indicated that different types of $\mathrm{OW}$ increased the length of aliphatic chains in soil HA however the different types of $\mathrm{OW}$ affected the $\mathrm{C}=\mathrm{H} / \mathrm{C}=\mathrm{O}$ ratio differently Table S1. Long term application of different organic and chemical fertilizers in black soil increased the area of aliphatic bonds in soil HA, as the ratio of $\mathrm{C}-\mathrm{H}$ increased in the amended plots when compared with the control [15]. The general increase in the $\mathrm{C}=\mathrm{H} / \mathrm{C}=\mathrm{O}$ ratio may be due to increased microbial activity under aerobic conditions, which could boost the content of hydroxyl and aliphatic groups [63]. Similar results have also been obtained by previous studies where the black soil was modified by different manure quantities [64]. This finding shows the greater 
efficiency of OW treatments in black soil and increased soil organic carbon activation [65]. Overall, the results of FT-IR spectrum analysis for soil HA were in agreement consistent with the elemental analysis of soil HA [66].

\section{${ }^{13} \mathrm{C}-\mathrm{NMR}$ Characteristics of Soil HA under Nine Years OW Treatments of Black Soil}

In this study, we used the ${ }^{13} \mathrm{C}$ - NMR technique to study the effects of different OW amendments on soil $\mathrm{HA}$ and the results have shown that the OW application may cause changes in chemical characteristics of soil HA. Similar results have been recorded by $[8,67]$. The application of maize straw causes a decline in alkyl $\mathrm{C}$ and carbonyl $\mathrm{C}$, while $\mathrm{O}$-alkyl $\mathrm{C}$ and aromatic $\mathrm{C}$ of soil HA increases in long-term fertilization [45]. Dou, Zhang and $\mathrm{Li}$ [64] also found a significant increase of alkyl $\mathrm{C}$ in hydrophobic components and aliphatic features after the application of OW in black soil. In the present study, OW treatments decreased the amount of aromatic $\mathrm{C}$ and increased alkyl C, O-alkyl C, and carbonyl $\mathrm{C}$ content. Almendros, et al. [68] found that $\mathrm{O}$-alkyl $\mathrm{C}$ was related to organic acids including fatty acids and peptide structures after the application of OW. The functional group composition of soil HA in this study was consistent with [69] who reported that the application of $\mathrm{OW}$ increased $\mathrm{O}$ - alkyl $\mathrm{C}$, aliphatic $\mathrm{C} /$ aromatic $\mathrm{C}$ ratios while it decreased hydrophobic $\mathrm{C}$ and aromatic $\mathrm{C}$ ratios. This was due to the presence of high carbohydrates in the O-alkyl C [50]. In addition, higher alkyl $\mathrm{C}$ in $\mathrm{OW}$ may be due to the lipids found in different OW compounds [70]. The higher aliphatic $\mathrm{C}$ in the OW treatments is mainly due to the process of decomposition of the OW which resulted in the production of aliphatic compounds [71]. In this study, we also found that $\mathrm{O}$-alkyl $\mathrm{C}$ was positively associated with SOC, alkyl C, and soil HA contents, and negatively correlated with aromatic $\mathrm{C}$, carbonyl $\mathrm{C}, \mathrm{C} / \mathrm{N}$ ratio, E4/ $\mathrm{E} 6$ ratio, and $\mathrm{H} / \mathrm{C}$ ratio, demonstrating that a good percentage of O-alkyl $\mathrm{C}$ was contained in soil HA. Soil HA substance it derives mostly from plant residue decomposer and made up the cellulose and lignin in the soil organic matter together with derived from primary and secondary compounds from crop residues, and microbial community $[72,73]$. This $\mathrm{O}$-alkyl $\mathrm{C}$ fraction was primarily due to the cellulose and hemicellulose in the OW [74, 75] and a good indicator of soil HA molecular composition [76]. Li, et al. [77] showed that the relationship between alkyl $\mathrm{C}$, O-alkyl $\mathrm{C}$, aromatic $\mathrm{C}$, and carbonyl $\mathrm{C}$ content of the cellulose-degrading microbial community are of effective relevance in terms of SOC change in agriculture soil. The same author indicated that $\mathrm{O}$-alkyl $\mathrm{C}$ content was strongly linked with the composition of the cellulose-degrading microbial community in soil layers. The significant positive relationship between $\mathrm{O}$-alkyl $\mathrm{C}$ and SOC, alkyl $\mathrm{C}$ and soil HA content showed that the functional groups originated from the OW that was applied [78]. Our results showed that soil HA increased the decomposition of OW treatments and the hydrophobic $\mathrm{C} /$ hydrophilic $\mathrm{C}$ ratio showed greater stability than $\mathrm{CK}$, particularly for treatments TL and FG. This means that the O-alkyl group consisted of various $\mathrm{C}$ types that could efficiently be absorbed by the soil microbial community [79]. In addition, the negative relationship between $\mathrm{O}$ - alkyl $\mathrm{C}$ and aromatic $\mathrm{C}$, carbonyl $\mathrm{C}, \mathrm{C} / \mathrm{N}$ ratio, E4/E6 ratio, and $\mathrm{H} / \mathrm{C}$ ratio showed that the $\mathrm{OW}$ amendments could have a greater effect on the accumulation SOC and molecular composition of soil HA making the structure of soil HA more complex and stable. Similar results have also been obtained by previous studies where positive and negative relations occurred between 13C- NMR analysis and elemental composition in the amended plots [80, 81]. This was mainly due to the high stability of soil $\mathrm{HA}$, the high degree of intensification of soil HA, and high humification of soil HA [80].

In addition [74] studied the effect of long-term straw returning in soil and reported that the O-alkyl $\mathrm{C}$ correlated positively with SOC fractions and negatively with carbonyl $\mathrm{C}$ and alkyl $\mathrm{C}$, which increases the capacity to preserve $\mathrm{SOC}$ [13]. The $\mathrm{C} / \mathrm{N}$ ratio was known to affect the decomposition of $\mathrm{OW}$ rate, a negative relationship from this present study between O-alkyl $\mathrm{C}$ indicated that the $\mathrm{O}$-alkyl $\mathrm{C}$ was the first component decomposed by the microorganism [82]. $\mathrm{He}, \mathrm{He}, \mathrm{Xu}$, Zhang, Yang and Huang [78] reported that positively correlated SOC stock and four functional groups with cumulative $\mathrm{C}$ input and the conversion rate was highest in O-alkyl C. This was mainly due to fertilize soils under long term by OW such as maize, manure, and plant residue. The same author suggested that ${ }^{13} \mathrm{C}$ - NMR defined functional groups were primarily governed by soil characters $\mathrm{C} / \mathrm{N}$ ratio, $\mathrm{pH}$, and clay content. Our findings suggest that the positive correlation O-alkyl $\mathrm{C}$ with SOC, alkyl C, soil HA content indicted that these OW amendments could have a greater effect on the accumulation SOC [81]. Finally, changes in the chemical composition of soil HA and SOC are largely attributable to optimized conditions for the humification process delivered from soil OW amendments under the long term (nine years) [83].

\section{Conclusions}

The application of OW significantly changed the humus, SOC and soil HA characteristics compared to (CK) in black soil from the study. In order to study the dynamics of the soil structure and the compound, elemental composition, FTIR, and 13C- NMR were used under the effect of the long term application of OW in black Soil. Analysis of soil HA under OW treatments in black soil indicated that the lowest $\mathrm{E}_{4} / \mathrm{E}_{6}$ ratio, $\Delta \log \mathrm{K}$ value, and the hydrophobic $\mathrm{C} /$ hydrophilic $\mathrm{C}$ ratio of soil HA were recorded in TL whereas the lowest $\mathrm{C} / \mathrm{H}$ ratio was recorded in the $\mathrm{OW}$ treatments with the exception of treatment $\mathrm{MR}$, which recorded 
high $\mathrm{C} / \mathrm{H}$ ratio. The negative relationship between $\mathrm{O}-$ alkyl $\mathrm{C}$ and aromatic $\mathrm{C}$, carbonyl $\mathrm{C}, \mathrm{C} / \mathrm{N}$ ratio, $\mathrm{E} 4 / \mathrm{E} 6$ ratio, and $\mathrm{H} / \mathrm{C}$ ratio showed that the $\mathrm{OW}$ amendments had a greater effect on the accumulation of SOC and improving the molecular composition of soil HA during the nine years. The application of OW appeared to be an important factor that resulted in the variation of soil HA composition and quality. TL was the most effective treatment in this study for the improvement of SOC accumulation and the strength and stability of the HA soil structure. In conclusion, the effect of long term (nine years) application of OW in this study was highly beneficial in increasing SOC and soil HA contents in black soil. This leads to sustainable development, soil fertility enhancement, plant growth, and improved productivity.

\section{Conflict of Interest}

All the authors declare no conflict of interest.

\section{Acknowledgements}

We are greatful for the research was financially supported by the Research Foundation of the Science and Technology Agency of Jilin Province, China (20190301018NY) and the National Key R\&D Program of China (2018YFD0300203, 2017YFD0201801).

\section{References}

1. XIE Z., ZHU J., LIU G., CADISCH G., HASEGAWA T., CHEN C., SUN H., TANG H., ZENG Q. Soil organic carbon stocks in China and changes from 1980s to 2000s. Global Change Biology. 13, 1989, 2007.

2. ZHANG Y.W., ZHIGANG GUO, HUOSHENG MENG, DONGFANG WANG, YANG AND WONG, Po-keung. Interaction between microbes DNA and atrazine in black soil analyzed by spectroscopy. CLEAN-Soil, Air, Water. 43, 867,12015.

3. NORMAND A.E., SMITH A.N., CLARK M.W., LONG J.R., REDDY K.R.J.S.S.S.O.A.J. Chemical composition of soil organic matter in a subarctic peatland: influence of shifting vegetation communities. Journal Soil Science Society of America.81, 41, 2017.

4. LEIFELD J., KNABNER I. Changes in the chemical composition of soil organic matter after application of compost. European Journal of Soil Science. 53, 299-, 2002.

5. DOU S., WANG S. Review of different microorganisms effect on humus formation. Journal of Jilin Agricultural University. 33, 119, 2011.

6. SENESI N., MIANO T., BRUNETTI G. Humic-like substances in organic amendments and effects on native soil humic substances. In Humic substances in terrestrial ecosystems, Elsevier: 531, 1996.

7. TAN K.H. Humic matter in soil and the environment: principles and controversies; CRC Press: 2014.

8. DOU S., HUA S. Effect of organic manure application on of humic acids characteristics of soil by 13 C-NMR spectroscopy. Journal of Jilin Agricultural University. 21, 43, 1999.

9. WATANABE A., SARNO; RUMBANRAJA J., TSUTSUKI K., KIMURA M. Humus composition of soils under forest, coffee and arable cultivation in hilly areas of south Sumatra, Indonesia. European journal of soil science.52, 599, 2001.

10. ZHANG X., LIU, Z., LIU X., LIANG X. Relationship between soil humus dissimilation, soil biological and chemical properties, and leaf litter characteristics in pure forests. Emirates Journal of Food Agriculture, ecosystems \& environment. 28, 161, 2016.

11. SONG X.-Y., LIU S.-T., LIU Q.-H., ZHANG W.-J., HU C.G. Carbon sequestration in soil humic substances under long-term fertilization in a wheat-maize system from North China. Journal of Integrative Agriculture. 13, 562, 2014.

12. CHEN X., MAO A., ZHANG Y., ZHANG L., CHANG J., GAO H., Thompson M.L. Carbon and nitrogen forms in soil organic matter influenced by incorporated wheat and corn residues. Soil Science Plant Nutrition. 63, 377, 2017.

13. ZHANG J., ZHANG L., WANG P., HUANG Q., YU G., LI D., SHEN Q., RAN W. The role of non-crystalline Fe in the increase of SOC after long-term organic manure application to the red soil of s outhern $\mathrm{C}$ hina. European journal of soil science.64, 797, 2013.

14. HU J., WU J., QU X., LI J. Effects of organic wastes on structural characterizations of humic acid in semiarid soil under plastic mulched drip irrigation. Chemosphere. 200, 313, 2018.

15. ZHANG J., WANG J., AN T., WEI D., CHI F., ZHOU B. Effects of long-term fertilization on soil humic acid composition and structure in Black Soil. PloS one. 12, e0186918, 2017.

16. QU X., WU J., ZHAO J., LI J., HU J., YAA O.K. Effects of Solid Organic Wastes on Soil Particulate Organic Carbon Structure Under Different Water Conditions. CLEANSoil, Air, Water.47, 1900187, 2019.

17. ROSSEL R.V., BEHRENS T. Using data mining to model and interpret soil diffuse reflectance spectra. Geoderma. 158, 46, 2010.

18. PEDERSEN J.A., SIMPSON M.A., BOCKHEIM J.G., KUMAR K. Characterization of soil organic carbon in drained thaw-lake basins of Arctic Alaska using NMR and FTIR photoacoustic spectroscopy. Organic geochemistry. 42, 947, 2011.

19. WALKLEY A., BLACK I.A. An examination of the Degtjareff method for determining soil organic matter, and a proposed modification of the chromic acid titration method. Soil science. 37, 29, 1934.

20. ATIA A., MALLARINO A. Agronomic and environmental soil phosphorus testing in soils receiving liquid swine manure. Soil Science Society of America Journal. 66, 1696, 2002.

21. LU R. The analytical methods for soil and agrochemistry. Beijing: China Agricultural Science and Technology Press. 2000.

22. GUAN S., DOU S., CHEN G., WANG G., ZHUANG J. Isotopic characterization of sequestration and transformation of plant residue carbon in relation to soil aggregation dynamics. Applied Soil Ecology. 96, 18, 2015.

23. KUWATSUKA S., WATANABE A., ITOH K., ARAI S. Comparison of two methods of preparation of humic and fulvic acids, IHSS method and NAGOYA method. Soil Science and Plant Nutrition. 38, 23-30, 1992. 
24. DOU S., TAN S., XU X., CHEN E. Effect of pig manure application on the structural characteristics of humic acid in brown soil. Pedosphere. 1, 345, 1991.

25. DOU S., Y.S.Q., ZHANG J.J. Effects of carbon dioxide concentrationon humus formation in corn stalk decomposition. Acta Pedologica Sinica, 43, 458, 2007.

26. CAMPITELLI P., CEPPI S. Effects of composting technologies on the chemical and physicochemical properties of humic acids. Geoderma 144, 325, 2008.

27. SAVY D., MERCL F., COZZOLINO V., SPACCINI R., CANGEMI S., PICCOLO A. Soil amendments with lignocellulosic residues of biorefinery processes affect soil organic matter accumulation and microbial growth. Sustainable ChemistryEngineering. 8, 3381, 2020.

28. ZHU P., REN J., WANG L., ZHANG X., YANG X., MACTAVISH D. Long-term fertilization impacts on corn yields and soil organic matter on a clay-loam soil in Northeast China. Journal of Plant Nutrition and Soil Science. 170, 219, 2007.

29. YANG F., TIAN J., FANG H., GAO Y., XU M., LOU Y., ZHOU B., KUZYAKOV Y.J.J.O.S.S. Functional soil organic matter fractions, microbial community, and enzyme activities in a mollisol under 35 years manure and mineral fertilization. Journal of Soil SciencePlant Nutrition. 19, 430, 2019.

30. GUO Z., ZHANG Z., ZHOU H., WANG D., PENG X.J.S.R. The effect of 34-year continuous fertilization on the SOC physical fractions and its chemical composition in a Vertisol. Scientific reports. 9, 2505, 2019.

31. LONG P., SUI P., GAO W., WANG B., YAN L., XING Y., CHEN Y. Effects of agricultural organic wastes incorporation on soil organic carbon and microbial carbon. Journal of China Agricultural Universit. 20, 1530, 2015.

32. QU X., WU J., ZHAO J., LI J., HU J., YAA O.K. Effects of Solid Organic Wastes on Soil Particulate Organic Carbon Structure Under Different Water Conditions. CLEAN-Soil, Air, Water. 47, 1900187, 2019.

33. VALENCIA S., MARÍN J.M., RESTREPO G., FRIMMEL F.H. Application of excitation-emission fluorescence matrices and $\mathrm{UV} / \mathrm{Vis}$ absorption to monitoring the photocatalytic degradation of commercial humic acid. Science of the Total Environment. 442, 207, 2013.

34. WAGNER M., SCHMIDT W., IMHOF L., GRÜBEL A., JÄHN C., GEORGI D., PETZOLDT H. Characterization and quantification of humic substances 2D-Fluorescence by usage of extended size exclusion chromatography. Water research. 93, 98, 92016.

35. LI F., KONG Q., ZHANG Q., WANG H., WANG L., LUO T. Spent mushroom substrates affect soil humus composition, microbial biomass and functional diversity in paddy fields. Applied Soil Ecology. 149, 103489, 2020.

36. SONG G., NOVOTNY E.H., MAO J.-D., HAYES M.H.B. Characterization of transformations of maize residues into soil organic matter. Science of The Total Environment. 579, 1843, 2017.

37. SIX J., CONANT R.T., PAUL E.A., PAUSTIAN K., soil. Stabilization mechanisms of soil organic matter: implications for C-saturation of soils. Plant soil. 241, 155, 2002.

38. DANISE T., FIORETTO A., INNANGI M.J.E.J.O.S.S. Spectrophotometric methods for lignin and cellulose in forest soils as predictors for humic substances. European Journal of Soil Science. 69, 856, 2018.

39. INGELMO F., MOLINA M.J., SORIANO M.D., GALLARDO A., LAPEÑA L. Influence of organic matter transformations on the bioavailability of heavy metals in a sludge based compost. Journal of environmental management. 95, 104, 2012.

40. DOU S., JIANG Y. Effect of application of organic materials on the properties of humic substances in organomineral complexes of soils. Acta Pedol Sin. 25, 252, 1988.

41. BARANČÍKOVÁ G., JARZYKIEWICZ M., GÖMÖRYOVÁ E., TOBIAŠOVÁ E., LITAVEC T. Changes in forest soil organic matter quality affected by windstorm and wildfire. Journal of soilssediments. 18, 2738, 2018.

42. WANG C., HE N., ZHANG J., LV Y., WANG L. Longterm grazing exclusion improves the composition and stability of soil organic matter in Inner Mongolian grasslands. PloS one. 10, e0128837, 2015.

43. CHEN X., WU J., OPOKU-KWANOWAA Y. Effects of Returning Granular Corn Straw on Soil Humus Composition and Humic Acid Structure Characteristics in Saline-Alkali Soil. Sustainability. 12, 1005, 2020.

44. FAN W., WU J., LI J., HU J. Comparative effects of different maize straw returning modes on soil humus composition and humic acid structural characteristics in Northeast China. Chemistry and Ecolog. 34, 355, 2018.

45. MENG A.-H., WU J.-G. Effects of different cow dung treatments on humus structure of vegetable planting soil. Journal of Soil Water Conservation. 29, 223, 2015.

46. DIGNAC M.-F., KNICKER H., KÖGEL-KNABNER I. Effect of $\mathrm{N}$ content and soil texture on the decomposition of organic matter in forest soils as revealed by solid-state CPMAS NMR spectroscopy. Organic Geochemistry. 33, 1715, 2002.

47. FURTADO E SILVA J.A.M., BRASIL DO AMARAL SOBRINHO N.M., GARCÍA A.C., PANDOLFO C.M., DA VEIGA M. Mitigation of Heavy Metal Contamination in Soil via Successive Pig Slurry Application. Soil Sediment and Contamination.26, 675, 2017.

48. DEBSKA B., SZOMBATHOVA N., BANACH-SZOTT M. Properties of humic acids of soil under different management regimes. Pol J Soil Sci. 42, 131, 2009.

49. BARANČÍKOVÁ G., JARZYKIEWICZ M., GÖMÖRYOVÁ E., TOBIAŠOVÁ E., LITAVEC T. Changes in forest soil organic matter quality affected by windstorm and wildfire. Journal of Soils and Sediments. 18, 1, 2018.

50. PLAZA C., SENESI N., GARCÍA-GIL J.C., BRUNETTI, G., D’ORAZIO V., POLO A. Effects of pig slurry application on soils and soil humic acids. Journal of agricultural food chemistry. 50, 4867, 2002.

51. ALVARENGA P., PALMA P., MOURINHA C., FARTO M., DÔRES J., PATANITA M., CUNHA-QUEDA C., NATAL-DA-LUZ T., RENAUD M., SOUSA J. Recycling organic wastes to agricultural land as a way to improve its quality: a field study to evaluate benefits and risks. Waste Management. 61, 582, 2017.

52. KOGUT B., KHOLODOV V. Water stability and labile humic substances of typical chernozems under different land uses. Eurasian soil science. 45, 496, 2012.

53. MOINET G.Y., CIERAAD E., HUNT J.E., FRASER A., TURNBULL M.H., WHITEHEAD D. Soil heterotrophic respiration is insensitive to changes in soil water content but related to microbial access to organic matter. Geoderma. 274, 68, 2016.

54. CUI T., ZHIHONG L., WANG S. Effects of in-situ straw decomposition on composition of humus and structure of humic acid at different soil depths. Journal of Soils and Sediments. 17, 2391, 2017. 
55. BARANČÍKOVÁ G., SENESI N., BRUNETTI G. Chemical and spectroscopic characterization of humic acids isolated from different Slovak soil types. Geoderma. 78, 251, 1997.

56. KUMADA K. Chemistry of soil organic matter; Elsevier: 17, 1988.

57. HUANG M., ZHU Y., LI Z., HUANG B., LUO N., LIU C., ZENG G. Compost as a soil amendment to remediate heavy metal-contaminated agricultural soil: mechanisms, efficacy, problems, and strategies. Water, Air, Soil Pollution, 227, 359, 2016.

58. ZALBA P., AMIOTTI N.M., GALANTINI J.A., PISTOLA S. Soil Humic and Fulvic Acids from Different Land-Use Systems Evaluated By E4/E6 Ratios. Communications in Soil Science and Plant Analysis. 47, 1675, 2016.

59. HU J., WU J., SHARAF A., SUN J., QU X. Effects of organic wastes on structural characterizations of fulvic acid in semiarid soil under plastic mulched drip irrigation. Chemosphere. 234, 830, 2019.

60. ZHAO N., LÜ Y.-Z. Effects of different fertilization treatments on soil humic acid structure characteristics. Spectroscopy Spectral Analysis. 32, 1856, 2012.

61. ZHANG J., HU F., LI H., GAO Q., SONG X., KE X., WANG L. Effects of earthworm activity on humus composition and humic acid characteristics of soil in a maize residue amended rice - wheat rotation agroecosystem. Applied Soil Ecology. 51, 1, 2011.

62. FETZNER S. Bacterial degradation of pyridine, indole, quinoline, and their derivatives under different redox conditions. Appl Microbiol Biotechnol. 49, 237, 1998.

63. DOU S., ZHANG J., LI K. Effect of organic matter applications on 13C-NMR spectra of humic acids of soil. European Journal of Soil Science. 59, 532, 2008.

64. FAN W., WU J., AHMED S., HU J., CHEN X., LI X., ZHU W., OPOKU-KWANOWAA Y. Short-Term Effects of Different Straw Returning Methods on the Soil Physicochemical Properties and Quality Index in Dryland Farming in NE China. Sustainability. 12, 2631, 2020.

65. ZHU Y., YANG K., SHAN R., HAN Z., SHAO Y., TIAN C. The Influence of Humification Degree of Humic Acid on Its Sorption of Norfloxacin During Sewage Sludge Composting. Water, Air, \& Soil Pollution, 229, 160, 2018.

66. WU J., REN J., ZHAO X., LI J. Morphology of humus in black soil as affected by fertilization method. Acta Pedologica Sinica. 51, 709, 2014.

67. ALMENDROS G., TINOCO P., DE LA ROSA J.-M., KNICKER H., GONZÁLEZ-PÉREZ J.-A., GONZÁLEZVILA F. Selective effects of forest fires on the structural domains of soil humic acids as shown by dipolar dephasing 13C-NMR and graphical-statistical analysis of pyrolysis compounds. Journal of Soils and Sediments. 18, 1303, 2018.

68. ZHANG J., CAO Z., FENG G., LI M., LI C., GAO Q., WANG L. Effects of Integrated Soil-Crop System Management on Soil Organic Carbon Characteristics in a Primosol in Northeast China. Pedosphere. 27, 957, 2017.

69. LIN Z., LI Y., TANG C., LUO Y., FU W., CAI X., LI Y., YUE T., JIANG P., HU S., ET Al. Converting natural evergreen broadleaf forests to intensively managed moso bamboo plantations affects the pool size and stability of soil organic carbon and enzyme activities. Biology and Fertility of Soils. 54, 467, 2018.

70. CHEN L., LI F., LI W., NING Q., LI J., ZHANG J., MA D., ZHANG C. Organic amendment mitigates the negative impacts of mineral fertilization on bacterial communities in Shajiang black soil. Applied Soil Ecology. 150, 103457, 2019.

71. BERG B., MCCLAUGHERTY C. Decomposition as a process: some main features. In Plant Litter, Springer. 11, 2014.

72. LEHMANN, J., KLEBER, M. The contentious nature of soil organic matter. Nature. 528, 60, 2015.

73. KUBAR K.A., HUANG L., LU J., LI X., XUE B., YIN Z. Long-term tillage and straw returning effects on organic $\mathrm{C}$ fractions and chemical composition of SOC in rice-rape cropping system. Archives of Agronomy and Soil Science, 65, 125, 2018.

74. TAMBONE F., ORZI V., ZILIO M., ADANI F. Measuring the organic amendment properties of the liquid fraction of digestate. Waste management. 88, 21, 2019.

75. DANISE T., FIORETTO A., INNANGI M. Spectrophotometric methods for lignin and cellulose in forest soils as predictors for humic substances. European Journal of Soil Science. 69, 856, 2018.

76. LI Y., LI Y., CHANG S.X., LIANG X., QIN H., CHEN J., XU Q. Linking soil fungal community structure and function to soil organic carbon chemical composition in intensively managed subtropical bamboo forests. Soil Biology and Biochemistry. 107, 19, 2017.

77. HE Y., HE X., XU M., ZHANG W., YANG X., HUANG $\mathrm{S}$. Long-term fertilization increases soil organic carbon and alters its chemical composition in three wheat-maize cropping sites across central and south China. Soil and Tillage Research. 177, 79, 2018.

78. LI Y., ZHANG J., CHANG S.X., JIANG P., ZHOU G., FU S., YAN E., WU J., LIN L. Long-term intensive management effects on soil organic carbon pools and chemical composition in Moso bamboo (Phyllostachys pubescens) forests in subtropical China. Forest Ecology Management. 303, 121, 2013.

79. SONG X., LIU J., JIN S., HE X., LIU S., KONG X., DONG $\mathrm{F}$. Differences of $\mathrm{C}$ sequestration in functional groups of soil humic acid under long term application of manure and chemical fertilizers in North China. Soil and Tillage Research. 176, 51, 2018.

80. YUE X., LI S., HUSSAIN Q., JIN S., LIU Q., CUI D., SONG X. Transformation of humic substances and functional groups of soil organic carbon after wildfire. Archives of AgronomySoil Science. 1, 2019.

81. INCERTI G., BONANOMI G., GIANNINO F., CARTENİ F., SPACCINI R., MAZZEI P., PICCOLO A., MAZZOLENI S. OMDY: a new model of organic matter decomposition based on biomolecular content as assessed by 13C-CPMAS-NMR. PlantSoil, 411, 377, 2017.

82. PETERS S., WANDER M., SAPORITO L., HARRIS G., FRIEDMAN D.J.S.O.M.I.T.A.T.E.I.N.A. Management impacts on SOM and related soil properties in a long-term farming systems trial in Pennsylvania. Soil Organic Matter in Temperate AgroecosystemsLong Term Experiments in North Americ. 183, 2019. 
Table S1. Relative intensities of peak heights in FTIR analysis of soil HA under the different treatments.

\begin{tabular}{|c|c|c|c|}
\hline Treatments & $\mathrm{C}-\mathrm{H}$ & $\mathrm{C}=\mathrm{O}$ & $\mathrm{C}-\mathrm{H} / \mathrm{C}=\mathrm{O}$ ratio \\
\hline $\mathrm{CK}$ & 0.359 & 0.703 & 0.510 \\
\hline FG & 0.646 & 1.953 & 0.330 \\
\hline MR & 0.610 & 1.112 & 0.549 \\
\hline MS & 0.738 & 2.165 & 0.340 \\
\hline TL & 0.893 & 1.623 & 0.550 \\
\hline
\end{tabular}

$\mathrm{C}-\mathrm{H}$ bonds in the $2920-2850 \mathrm{~cm}^{-1}$ region, $\mathrm{C}=\mathrm{O}$ bonds in the $1720-1640 \mathrm{~cm}^{-1}$ region and ratio of $\mathrm{C}-\mathrm{H} / \mathrm{C}=\mathrm{O}$. 